\title{
Gross Motor and Social Development of Children Development Media of Traditional Jumping Rope Modification Game
}

\author{
Heppy Zakiatun Nissa ${ }^{1, a^{*}}$, Mustaji ${ }^{1, b}$, Hendratno ${ }^{1, c}$ \\ 1Primary Education, Postgraduate, Universitas Negeri Surabaya, Indonesia \\ a heppynissa16070855043@mhs.unesa.ac.id; b mustaji@unesa.ac.id; c hendratno@unesa.ac.id \\ *Corresponding Author : a zeinor.18009@mhs.unesa.ac.id | Phone :085606200285
}

\begin{abstract}
The purpose of this research is to know the validity, practicality and effectiveness of media traditional jumping rope modification game to improve the development of gross motor and social of children. The research method used Dick and Carey model development research with the following steps: a). Analyzing the need, b.) Analyzing learning, c.) Analyzing child characteristics and learning context, d.) Formulating specific learning objectives, e.) Develop research instruments, f.) Develop learning strategies, g.) Develop teaching materials, h.) Designing and implementing formative evaluation, i.) Revising learning. The subject of research taken is kindergarten children aged 5-6 years as much as 54 children. The subject of research also involves 2 material experts and media experts. Data collection using a product feasibility test poll from media experts and material experts, interviews on individual trials, interviews on small group trials and observation sheets on field trials with indicators on gross motor development, among others, coordinated body movements to train flexibility, balance and agility, jump over obstacles with a height of $20-40 \mathrm{~cm}$, and perform a leap of 38-60 cm towards the target with obstacles. As for indicators of social development, among others, obey the rules of the game, play with peers, be cooperative with friends, and realize the rights and interests of others. Data analysis techniques using the N-Gain Score index. Development research resulted the product of the Game media usage Guide Book of "Lokota" and the Media game "Lokota" that has got validation of material experts and media experts with excellent results so it is worth using.
\end{abstract}

Keywords: Gross motor development; Social development; Media of traditional game

\section{Introduction}

In fact each child has the same potential to thrive. These potentials can be optimally honed as a way of boosting the child's ability. The child is born, grows and develops in the first environment, which is the environment where the first father and mother were interacting with the child. All the first knowledge gained by the child comes from interactions with the elderly and the surrounding environment. The potential will develop as the child grows and develops and it determines the lives of children in the future. The child's potential will be a strength for the child when it gets attention from his or her parents. One of the efforts that parents can do is to give children the opportunity to get educated thgross early childhood education (PAUD).

Sistem Pendidikan Nasional No. 20 of 2003 confirms that the early childhood education is a coaching effort aimed at children from birth to age six thgross the introduction of education to help the growth and development of the physical and spiritual so that the child is ready to go to the next level of education [1]. The article provides an implied message that early childhood has enormous potential for future success. At this age is a golden opportunity that must be optimised to become a generation of Indonesian children who are useful for nations and nations.

The development potential in early childhood consists of six aspects of development. That aspect is formed from birth so it is not yet perfect and requires a touch of stimuli to develop it. This aspect of development establishes the children completely and is responsible for the various abilities and skills that children have. Skill in early childhood is not necessarily mastered suddenly, but it requires a long process. Various aspects of a well-stimulated child's development will help the child thgross future challenges with a 
more complex life. The future presents a variety of complex problems that demand a healthy physical situation and good mobility because of the many things that the children will be traversed in the future. Suryana stated that stimulation in gross motor aspects is believed to make the child's growth grow optimally, making the child agile, supple, and strong in conducting various activities [2]. This aspect of development plays a major role in daily activities.

The characteristics of early childhood are active in moving and doing various activities become one manifestation of fulfilling the needs of children will learn. Pica and Berdekamp state that early childhood explores the environment so that aspects of gross motor development and other developments such as social, emotional, creativity, cognitive and art can be increased [3].

Based on the opinions of Sujiono, gross motor development is all the movements carried out by the body that develops from the element of maturity and control of gestures [4]. Gross motor development is very important to be honed early because it relates to the moving capability that is the daily activity of humans. Especially in early childhood children who use gross motor capability especially gross motor to perform activities such as walking, running, skipping and other gross motor motion ability. The child does so as an effort to learn from his environment thgross movement exploration. This ability, according to Akbar, grew rapidly from an early age and it is "an opportunity for educators to maximize the potential of children's own" [5].

Habituation of children to enjoy moving will be better when at an early age. Wijaya stated that childhood is referred to as the ideal period for studying coarse motor skills [6]. At this age, the child has a body that is still supplible and flexible, easy to learn new things, more likely to dare to experiment, liking repetition and the child has more time to learn gross motor skills especially gross motor. Based on the opinions of Adriani \& Wirjatmadi, coarse motor skills include the entire body or part movements which include endurance, speed, flexibility, dexterity, balance and strength influenced by the maturity of the child itself [7]. In line with the above opinion, the child's gross motor development accompaniments the growth dan kematangan fisik anak. Sesuai pendapat Suryana, semakin matang perkembangan motorik kasar anak, maka keadaan fisik semakin kuat dan keterampilan Children's movements will be more skilled according to their age [8].

Based on the opinions of Sukamti, the ability to perform physical movements and actions in a child is related to self-confidence and self-concept formation [9]. The establishment of such abilities is important to be honed early because early childhood is an individual who is essentially a social creature that other human needs to be able to survive. The aspect of early childhood social development is a good start in instilling the ability to socialize and connect with friends in their environment. Good gross motor ability to form self image in children that resulted in the child get appreciation from the people around him so that the self esteem also increased as in the results of the research done by Ellerman in 1980 [10].

The need to stimulate social development also needs to get attention in particular. The results of the research conducted by Lawhon and Lawhon, children who do not have friends to play and do not know the value of friendship will have a feeling of rejection and experiencing social emotional disorder [11]. Other research results from Clelland and Weinberger in 1991 showed that the adult social life was very concerned with parenting in children [12]. Bandura stated that learning received at an early age thgross an educational institution would be very effective in developing a child's social behaviour according to rules and norms supported by the strengthening of its environment [13]. Furthermore, the influence of educational institutions is not only on academic ability and achievement, but also affects the psychosocial children [14].

Peraturan Menteri Pendidikan Republik Indonesia No. 137 Tahun 2014 Article 13 states that "the implementation of learning is done by playing interactively, inspiring, enjoyable, and child-centered to actively participate and to provide freedom to initiative, creativity and independence in accordance with children's physical and psychological talents, interests and developments" [15]. The regulation implies that educators need to implement creative and make The child active to move thgross play.

Based on the findings in the field, the teacher's reality is less concerned with variations in learning, especially in the use of media that still uses books as the main media. Use of media books in the classroom has an impact on stimulating developmental aspects that are less than optimal and result in low children's learning ability. Teachers also expect optimal learning outcomes but efforts to use the media as teaching aids are minimal.

Results of the development of children at the age of 5-6 years referring to Permendikbud number 137 year 2014 about the national standard of Early child Education on the physical development aspect of gross motor in the achievement of performing movements coordinated to train flexibility, balance and agility that many children get the value of start developing (MB).

Likewise with social development. The absence of media that accommodates the development of children in Permendikbud number 137 year 2014 in playing with peers and is cooperative, resulting in children getting less stimulus so that it affects the behavior of a child group B who chooses aggressive way 
such as hitting, snapped, snatch the toy of friends grossly to resolve the conflict. It affects the quality of friendship and also affects the child to be cooperative with other friends so that most children get the value of starting to grow $(\mathrm{MB})$ on the achievement of social development.

Therefore, the need for learning variation is done in learning such as using media that facilitate in learning activities. The use of media to improve the development of gross and social motor of early childhood can be done using cultural media that is identical with mutual cooperation and togetherness and involve physical activity in it. So the development of traditional game media became necessary to be dikreasikan by combining the elements of education into a learning medium in the classroom.

Wahyudin argues that stimulation of gross motor and social development can be stimulated by the utilization of learning Media [17]. Therefore, researchers want to help optimize the development of gross and social motor children with the help of utilization of media. Angkowo in Musfiqon stated that difficulties in presenting objects in learning will be easier to convey with learning media, in addition to the an be stimulated with learning media [18]. Vebrianto and Osman also say that the media is an important main component in the learning process [19].

The results of the analysis above, then the author is interested to do research activities thgross the development of real media in the form of traditional game media. This media selection was based on the media selection process by Anderson in a Munadi adjusted to the problem of group B's child in TK DWP Randegansari [20]. The media selection process consists of several phases and is recommended to use media II and VII namely print media and real media. The selected print media is a media arena playing from banners and Gaco as well as real objects selected researchers are rubber straps.

This Media is made from the traditional game modification of the jumping rope that already exists. Traditional game type jumping rope is chosen because it corresponds to the problem that is in TK DWP Randegansari. The traditional game of jumping rope combines the movement of jumping activities and elements of group game cooperation. Moreover, on the basis of traditional games because the development of the traditional games is no longer played by the community so that children also do not play. In fact, this game is the cultural heritage of the nation that must be preserved and children can learn many things while playing thgross the traditional games such as social behavior, physical, emotion and others. The negative side of modern games based on technology causes the child to play passively compared to traditional games. The statement is evidenced by Yossie Christy Thenue's Research (2013) with the title of understanding the child's interpersonal communication experience with regard to changing traditional game play habits into a modern, technology-based game [21].

The result that children play with modern games based on technology brings a negative impact on the child's behavior when communicating with people around him. Children demonstrate selfish attitudes, individualist, laziness, violence and affiliative behaviour. In addition, the child is unable to maintain familiarity with friends who are shown with the low desire of children to maintain their togetherness and weak commitment to friendship. In contrast, traditional games that require a friend to start the game, make the child have the opportunity to communicate with other children and build friendships.

The content of cultural values and local wisdom make traditional games in each region has its own characteristic. The similarities are to uphold the togetherness of society, hard work, mutual assistance, cooperation, honest, and patient. One of the many traditional games is the traditional jumping rope game chosen to be further developed. It's a game that has simple rules and gameplay for kids. Mulyani stated that the traditional game of rope jumping is a game that is easy to play with a simple tool that is a rubber band that was used and as an obstacle when jumping [22]. This traditional game involves a lot of gross motor coordination of children so that the child is healthier and has many friends. Friend's help is needed to hold the rope as the child plays so the child's social spirit also develops

Traditional game media jumping rope modification is a game media consisting of rubber rope, play arena, and Gaco that is played by 3 groups of children. The Media is played by the way each child group of jumper brings Gaco image of their group name by relay from 1st child to 2nd Child, 2nd child to 3rd Child from the start line until finish line by jumping on the target image box according to the group name. The game rules of each child of a jumper group should not be meshed with a rope when jumping on a rope, if one of the children is caught, then the group changes into a rope holder group. The winners are determined by how many Gaco are successfully collected in the Gaco box at the finish line. Each child in the group has each role in jumping over the target drawing box at any height of the rubber strap to enhance the gross and social motor development. The game is performed with a seated strap holder.

Traditional game Media This modification contains many benefits among others can train coordination of body, training ability concentrates and fun. In addition, it is useful in shaping the atmosphere of healthy friendships and togetherness among players, honesty and sportsmanship all done joyfully. The challenge in each jump will give the child a distinctive impression to dare to jump according to the drawing box according to the group. 
Traditional game Media Jumping rope modification is part of a game of ancestral heritage tradition that contains cultural values and local wisdom and can hone various aspects of children's development [23]. According to Jonah the traditional game requires child creations and builds social activities in the community so that traditional games can be said to be a reflection of the culture surrounding society [24].

Based on the background exposure above, researchers raised a study titled "Traditional Game Media development jumping rope modification to improve the development of gross motor and social child group B in TK DWP Randegansari".

\section{Methods.}

Research development with the aim of producing new products thgross the development process integrated with the research activities. This development study used Dick and Carey's models with 9 development steps, a). Analyzing the needs, b.) Analyse learning, c.) To analyse child characteristics and learning contexts, d.) Formulating specific learning objectives, e.) Develop research instruments, f.) Develop a learning strategy, g.) Develop teaching materials, h.) Designing and implementing formative evaluation, i.) Revise learning.

The collection of data used among other product feasibility test sheets from media experts and material experts, which is used to assess the quality of the product is a check list form of poll to get the assessment of media experts and materials. Interview sheets on individual trials and in small group trials to get a response from a child's media usage. To know the effectiveness of the media used by the observation sheet in field tests.

The data analysis technique aims to determine the quality of the game media that has been developed based on media expert and material expert responses. Data analysis techniques are also performed on the outcome of the child's response after playing the product. After that it is also a data analysis technique to know the effectiveness of the game media with the N-Gain Score.

\section{Results and Discussions}

Based on the design of the development research submitted, the traditional game media development of jumping rope modification is done thgross 9 stages, namely:

Analyzing the needs. The results of an analysis of children aged 5-6 years that the child in the age group liked a challenging game and involved many physical rules and movements, as well as playing with his friends form a group.

\section{Analyzing Learning}

Learning analysis results show that the ability of children aged 5-6 years in coordinated movement, playing with peers, being cooperative with friends requires proper learning media.

\section{Analyzing Child Characteristics and context}

The result of the analysis of this stage is that the child is at age 5-6 years old where this age in the motor development has been ripe in STPPA children aged 5-6 years has been able to perform movements coordinated to train balance, flexibility and agility. On the aspect of social development, children aged 5-6 years old have been at the stage of knowing the rules, playing with peers, collaborating with friends and realizing the rights and interests of others so that children need learning using concrete and fun media in the form of group play.

\section{Formulating Specific learning objectives}

Special learning objectives include: children are able to perform physical games with the rules, the child is able to perform movements coordinated to train balance, agility and flexibility Well, the child is able to play with peers and the child is able to be cooperative with friends.

\section{Develops research instruments}

The instrument is used to measure the development of gross and social motor child using observation method using observation sheet with Rating scale assessment of the technique, consisting of criteria BSB = very good growth, $\mathrm{BSH}=$ develop as expected, $\mathrm{MB}=$ start growing, and $\mathrm{BB}=$ not yet developed. Assessment is used to measure the child's ability in the development of gross and social motor children before and after learning using media. 


\section{Develop a learning strategy}

The learning strategy that will be applied to this research is a direct learning strategy where the strategy directs the children thgross clear steps so that children can give a relatively fast response.

\section{Developing teaching materials}

The game used is a traditional game of jumping rope with the media: rubber rope, play arena, medallions and Gaco to improve the development of gross motor and social child group B with completed teacher manual making it easier to play.

\section{Designing and implementing formative evaluation}

At this stage researchers conduct product testing thgross expert validation stages, individual tests, small group tests and field trials.

\section{Media Expert Validation Result}

Table 1. Results validation of traditional game media jumping rope Modification

\begin{tabular}{|c|c|}
\hline Aspect rating & Average Score \\
\hline Safety & 5 \\
\hline Comfortable & 5 \\
\hline Interesting & 5 \\
\hline According to the Child Development level & 5 \\
\hline Utilize potential and resources in the surrounding environment as well as other items worthy of use & 5 \\
\hline Can be manipulated & 5 \\
\hline No harm to the health of children & 4,75 \\
\hline Easiness & 5 \\
\hline
\end{tabular}

Result Validation Guide Book Game Media Usage

Table 2. Result of validation of Game Media usage Handbook

\begin{tabular}{lc}
\hline \multicolumn{1}{c}{ Aspect Rating } & Average Score \\
\hline Serving & 5 \\
\hline Content of group B material (aged 5-6 years) & 5 \\
\hline Book Language & 5 \\
\hline Graphics & 4 \\
\hline
\end{tabular}

\section{Result Validation Guide Book Game Media Usage}

Table 3. Result of validation of traditional game material jumping rope modification

\begin{tabular}{|c|c|}
\hline Aspects Rating & Average Score \\
\hline Educative & 5 \\
\hline Technique & 5 \\
\hline Attractiveness & 5 \\
\hline
\end{tabular}

\section{Individual test results}

9 Children interview result in individual test with "yes" answer to all children so that the mean obtained is 1 with a percentage of $100 \%$ so that the media deserves to be used in subsequent trials without revision.

\section{Small group test result.}

The results of interviews in small group tests with respondents of 18 children were obtained the answer of the whole child answered "yes" with the mean obtained is 1 with a percentage of $100 \%$ so that the media deserves to be used in subsequent trials without revisions. Small group trial results also show products developed showing excellent qualifications so that no need to be revised 


\section{Gross Motor development Field test result}

Table 4. The results of N-Gain recapitulation of the child's gross motor development

\begin{tabular}{clccc}
\hline No & & N-Gain Categories & Number of Childre & Percentage (\%) \\
\hline 1 & Low & 1 & $2 \%$ \\
\hline 2 & Moderate & 4 & $8 \%$ \\
\hline 3 & High & 49 & $90 \%$ \\
\hline
\end{tabular}

\section{Social Development Field Trial Results}

Table 5. The Results of N-Gain Recapitulation of Children's Social Development

\begin{tabular}{clccc}
\hline No & & N-Gain Categories & Number of Children & Percentage (\%) \\
\hline 1 & Low & 4 & $7 \%$ \\
\hline 2 & Moderate & 12 & $22 \%$ \\
\hline 3 & High & 38 & $71 \%$ \\
\hline
\end{tabular}

Revision of learning is a corrective step towards the outcome of a formative evaluation which is considered less necessary or less precise so that the developed product can be more optimal.

The final product of this development is the traditional game media of jumping rope modification and the media Use guide book to stimulate the gross motor and social child group B. Traditional game Media of jumping rope modification consist of playground, rubber rope, Gaco and medal necklace. The playground is made from a flexi banner fabric measuring 3,5mx3, $5 \mathrm{~m}$ divided into two parts, the playground 1 and playground 2 that can be combined with each other. Rubber straps are made colorful with the accompanying containers to roll with a size of $3 \mathrm{~m}$ per rubber.

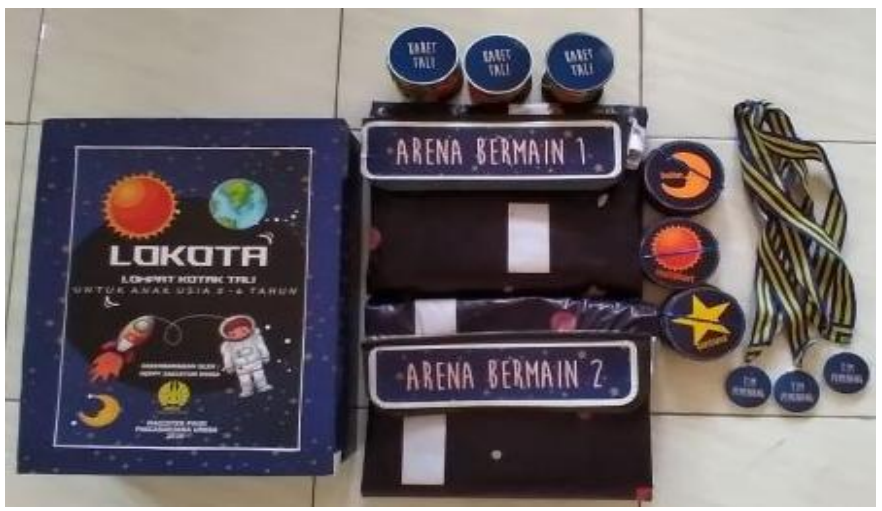

Figure 1. Traditional Media Game Jumping Rope Modification “Lokota”

Gaco images of Sun, Moon, and stars made of foam hearts and sticker paper measuring approximately $10 \mathrm{~cm}$ and a medal necklace made of cloth tape and pins $6 \mathrm{~cm}$ in diameter. Here are the media and guide books:

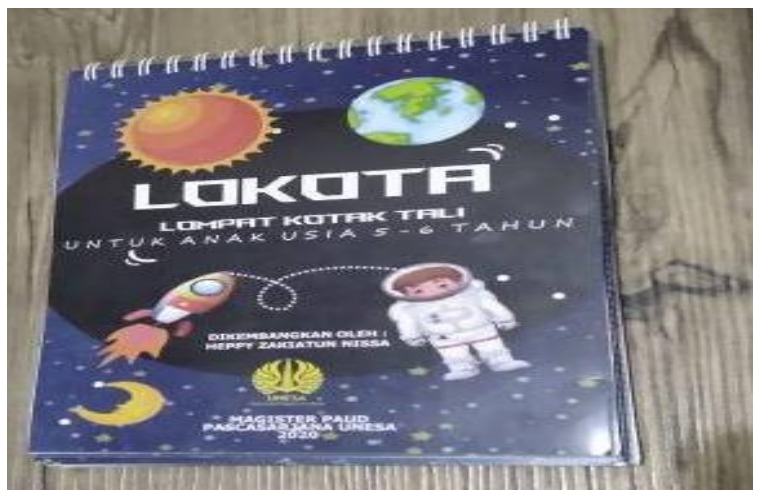

Figure 2. Media Usage Handbook

The media usage steps were the first child to choose a friend to be a group of 3 children in each group. The formed group was named after the Sun, moon and star groups. Representatives of each group performed Hompimpa to determine the group's first play/jumper group and the other two groups holding the rope. Each group has its own target drawing box. One of the children of the jumper group stood at the start line by carrying Gaco. Then, another child stands in another box close to the target image box. The play rules of the child standing in the start line must jump on each drawing box and jump over the strap rubber to the target image box while carrying gaco towards the second childs. 
After Gaco arrived in the second child, the second child jumped over the drawing box and jumped over the rope rubber to the target image box where the third child was located. The third child does the same thing as the second child and puts Gaco on the box at the finish line. All children return to their respective positions to receive their next Gaco. Height of rubber rope varies from chin on rubber strap first then on rubber strap second knee-length and on rubber strap third chest. The game is done with a seated strap holder. The group of players who first collected five Gaco on the finish line would be the winner and deserve a necklace of medals. When the Gaco falls, the group becomes a rope holding group, and when playing there is a child caught by a rope or jumping not according to the rules, the group turns into a rope holder.

Overall, the Media and guide book usage of the game media are stated to be feasible and effective for use in the learning process with a validation value of $98 \%$ of the category very valid in traditional game media jumping rope modification and $92 \%$ in the validation results of the Game Media usage Handbook. While the practicality of the use of media obtained results $100 \%$ of respondents stated that practical media for use and the results of media effectiveness get a percentage gain as much as $90 \%$ are in high category so that there is increased learning outcomes during pretests and posttest on gross motor capability. As for the social capability as much as $71 \%$ of children are in high category so increased results during pretests and posttest.

This is in line with the research result of Suhartini (2018) that the child's gross motor ability can increase when stimulated using traditional game media jumping rope [25]. The findings also supported the research by Kurniawati (2014) stating that the child's social skills could be improved the traditional games [26].

\section{Conclusion}

Based on the development studies that have been implemented, it was concluded that the media game jumping rope modification and the game media usage manual shows a very valid validity value, practicality value worth using, and the value of effectiveness, effective to improve the development of gross motor and social children group B in the KINDERGARTEN DWP Randegansari Driyorejo Gresik.

\section{References}

Adriani, M., \& Wirjatmadi, Bambang. (2014). Gizi dan Kesehatan Balita Peranan Micro Zinc pada Pertumbuhan Balita. Jakarta: Kencana Prenadamedia Group.

Akbar, H. (2001). Psikologi Perkembangan Anak. Jakarta:Grasindo.

Ayriza, Y., Izzaty, R.E., \& Setiawati, F.,A.,(2004-2006). Pengembangan Modul Social Skill Untuk Anak-Anak Prasekolah dan Model Sosialisasinya (Pusat Studi PAUD) diunduh dari https://journal.uny.ac.id/index.php/jpip/article/viewFile/16794/9940

Kurniawati, Mei Wulan. (2014). Peningkatan keterampilan sosial melalui permainan tradisional pada anak kelompok A TK Cemara Dua Surakarta tahun ajaran 2013/2014. Jurnal Kumara cendekia 2(1). Diunduh dari https://jurnal.uns.ac.id/kumara/article/view/32044/0

Madyawati. (2016). Strategi Pengembangan Bahasa pada Anak. Jakarta: Prenada Group

Munadi, Yudhi. (2012). Media Pembelajaran, Sebuah Pendekatan Baru. Jakarta: Gaung Persada Press

Peraturan Menteri Pendidikan Nasional nomor 137 tahun 2014 tentang Standar Nasional Pendidikan Anak Usia Dini

Sujiono, B., Sumantri, M.S., \& Chandrawati, T. (2014). Metode Pengembangan Fisik. Jakarta: Universitas Terbuka

Sukamti, E. R . (2007). Diktat Perkembangan Motorik (Diktat Pendidikan Kepelatihan Olahraga Fakultas Ilmu Keolahragaan Universitas Negeri Yogyakarta). Diunduh dari http://staffnew.uny.ac.id/upload/131568302/pendidikan/Diktat+Motorik.pdf

Seriati, N.N. (2010). Permainan Tradisional Jawa Gerak dan Lagu Untuk Menstimulasi Keterampilan Sosial Anak Usia Dini. Penelitian Pengabdian . Diunduh dari http://lppm.uny.ac.id/permainan-tradisional-jawagerak-dan-lagu-untuk-menstimulasi-keterampilan-sosial-anak-usia-dini

Suhartini. (2018). Meningkatkan Kemampuan Motorik kasar Melalui Permainan tradisional lompat tali Pada Usia 5-6 Tahun Di PAUD Tunas Mekar Plus Tahun Pelajaran 2017/2018. https://doi.org/10.24903/jw.v1i2.183

Suryana, D. (2016). Pendidikan Anak Usia Dini: Stimulasi dan Aspek Perkembangan Anak. Jakarta: Prenada Media

Thenu, Y. C., Lestari, S.B., \& Naryoso, A. (2013). Memahami Pengalaman Komunikasi Antarpribadi Anak Berkaitan dengan Perubahan Kebiasaan Bermain Permainan Tradisional menjadi Permainan Modern Berbasis Teknologi (Studi pada Anak-Anak di Dukuh Paren, Kelurahan Sidomulyo, Kecamatan Ungaran Timur, Kabupaten Semarang). Jurnal Interaksi Online, 1(4).

Vebrianto, R., Osman, Kamisah. 2011. The effect of Multiple media instruction in improving students science process skill and achievment. Jurnal Elsevier Procedia-Social and Behavioral Science halaman 346-350 
(15) Online. Diunduh dari https://www.sciencedirect.com/science/article/pii/S1877042811002783. https://doi.org/10.1016/j.sbspro.2011.03.099

Wijaya, A. M. (2009). Pentingnya Stimulasi, Deteksi dan Intervensi Dini tumbuh Kembang (SDIDTK) Anak. Jakarta: Departemen Pendidikan Nasional. 